\title{
Prospecting sugarcane genes involved in aluminum tolerance
}

\author{
Rodrigo D. Drummond ${ }^{1}$, Claudia T. Guimarães ${ }^{2}$, Juliana Felix ${ }^{1}$, Fernando E. Ninamango-Cárdenas ${ }^{3}$, \\ Newton P. Carneiro ${ }^{2}$ Edilson Paiva ${ }^{2}$ and Marcelo Menossi $i^{*}$
}

\begin{abstract}
Aluminum is one of the major factors that affect plant development in acid soils, causing a substantial reduction in yield in many crops. In South America, about $66 \%$ of the land surface is made up of acid soils where high aluminum saturation is one of the main limiting factors for agriculture. The biochemical and molecular basis of aluminum tolerance in plants is far from being completely understood despite a growing number of studies, and in the specific case of sugarcane there are virtually no reports on the effects of gene regulation on aluminum stress. The objective of the work presented in this paper was to prospect the sugarcane expressed sequence tag (SUCEST) data bank for sugarcane genes related to several biochemical pathways known to be involved in the responses to aluminum toxicity in other plant species and yeast. Sugarcane genes similar to most of these genes were found, including those coding for enzymes that alleviate oxidative stress or combat infection by pathogens and those which code for proteins responsible for the release of organic acids and signal transducers. The role of these genes in aluminum tolerance mechanisms is reviewed. Due to the high level of genomic conservation in related grasses such as maize, barley, sorghum and sugarcane, these genes may be valuable tools which will help us to better understand and to manipulate aluminum tolerance in these species.
\end{abstract}

\section{INTRODUCTION}

Aluminum is the most abundant metal in the lithosphere, comprising about $7 \%$ by mass of the earth's crust (Delhaize and Ryan, 1995). In soils with a pH higher than 5, aluminum is predominantly bound as insoluble oxides and complex aluminosilicates, while at the lower $\mathrm{pH}$ of more acid soils the ionic form $\left(\mathrm{Al}^{3+}\right)$ is released into the soil solution and becomes available to plants at toxic concentrations (Kinraide and Parker, 1989) and is the major limiting factor for crop production. Acid soils occupy $3.95 \times 10^{9}$ ha $(30 \%)$ of the world's ice-free land area, but in South America acid soils account for about $66 \%$ of the land area (Baligar and Ahlrichs, 1998). Strategies to maintain crop yield in these soils include the application of lime to raise the soil $\mathrm{pH}$ and the use of cultivars tolerant to this type of environment. As successive applications of lime lead to runoff pollution and other undesirable side effects, the manipulation of aluminum tolerance in crop species, either by conventional breeding or by genetic engineering, offers an environmentally clean and sustainable solution to improve productivity in acid soils.

The first and principal symptom of aluminum toxicity in plants is the inhibition of root growth, which causes a decrease in water and nutrient uptake and subsequent inhibition of plant growth. Despite a large amount of research in this area the physiological and biochemical mechanisms of both aluminum toxicity and tolerance in plants are far from being completely understood. A great number of hypothe- ses for aluminum toxicity have been suggested, including alteration of the cation-exchange capacity of cell walls, changes in the potential of the plasma membrane affecting the uptake of $\mathrm{Ca}^{2+}$ and/or $\mathrm{Mg}^{2+}$, induction of oxidative stress via lipid peroxidation, replacement of $\mathrm{Mg}^{2+}$ or $\mathrm{Fe}^{3+}$ by $\mathrm{Al}^{3+}$ in cellular reactions, interference with signal transduction, direct binding of aluminum to DNA and/or RNA and changes in the pectin matrix of root cell walls. There are arguments and indirect evidence supporting each of these possibilities (Delhaize and Ryan, 1995; Kochian, 1995) but to date there is little direct evidence favoring one hypothesis over another.

Because aluminum is a strong selective force many plant species have developed tolerance mechanisms to overcome this type of toxicity, yielding species and cultivars very well adapted to acid soils. There are two major groups of aluminum detoxification mechanisms, exclusion (apoplastic) mechanisms and internal (symplastic) mechanisms, the basic difference between the two being the site of detoxification (Taylor, 1991; Kochian, 1995). Exclusion mechanisms prevent aluminum from crossing the plasma membrane and getting inside plant cells (symplasts) while internal mechanisms immobilize, compartmentalize or detoxify this metal when it penetrates into cells (Zheng et al., 1998).

Genetic studies on aluminum tolerance have shown that ions of this metal induce the expression of genes involved in the general stress response of wheat, including

\footnotetext{
${ }^{1}$ Laboratório de Genoma Funcional, Centro de Biologia Molecular e Engenharia Genética, Universidade Estadual de Campinas, C.P. 6010, 13083-970 Campinas, SP, Brazil.

${ }^{2}$ Núcleo de Biologia Aplicada, Embrapa Milho e Sorgo, 35701-970 Sete Lagoas, MG, Brazil.

${ }^{3}$ Departamento de Biologia Aplicada, Faculdade de Agricultura e Veterinária, Universidade Estadual Paulista, 14870-000 Jaboticabal, SP, Brazil. Send corresponding to Marcelo Menossi.E-mail: menossi@unicamp.br.
} 
genes coding for phenylalanine ammonia lyase, protease inhibitors and a metalothionein-like protein (Snowden and Gardner, 1993). The nature of the stress induced by aluminum is not completely clear, although there are indications that an oxidative stress is induced in plant tissues exposed to this metal (Richards et al., 1998). The expression of several other genes has also been reported to be elicited by treatment with aluminum, showing that several metabolic pathways in the cell are changed in response to the stress caused by this metal.

A great number of aluminum tolerance studies have been carried out in maize, wheat and other grasses, although very few have addressed sugarcane. Landell (1989), working with several sugarcane varieties, observed a wide range of aluminum sensitivity, with $10 \mathrm{ppm}$ of aluminum causing a strong reduction in root growth in some Saccharum spontaneum varieties while Saccharum officinarum varieties exhibited higher levels of tolerance. Azeredo (1982) has found that in some aluminum-sensitive varieties $1.56 \mathrm{ppm}$ of this metal was able to cause root growth inhibition. However, to our knowledge, there have been no reports on sugarcane genes related to aluminum stress.

During the work presented in this paper we prospected the SUCEST database looking for sugarcane genes related to known genes involved in the response to aluminum stress in plants and yeast. This study is the first initiative to understand the mechanisms by which sugarcane plants deal with aluminum toxicity.

\section{METHODOLOGY}

Search for genes related to aluminum tolerance in other species

An extensive search for papers reporting aluminum-related genes from plants and microorganisms was performed using the Web of Science citation database (webofscience.fapesp.br) and aluminum-related genes were searched in the GenBank database (www.ncbi.nlm.nih. gov) by the accession numbers obtained in the literature and by using keywords. Protein sequences from the majority of the genes were obtained, but for a few genes only partial cDNA sequences were available.

\section{Search for sugarcane genes}

The cap3 cluster consensi from the SUCEST database sequence were prospected using two algorithms from the BLAST (basic local alignment search tool) family of programs, TBLASTN and TBLASTX, depending on the original source of information (amino acid or nucleotide sequence, respectively). Clusters were accepted as related to a particular gene when presenting e-values below $10^{-5}$.

\section{Evaluating similarities}

The open reading frames (ORFs) present at the cluster consensi identified above were translated according to the universal translation table, and the deduced proteins were aligned with the entire sequence of the respective protein obtained from the literature. The Clustalw software (Thompson et al., 1994) was used to perform the alignments and to check the similarity of the proteins that were matched by the sugarcane genes.

\section{Characterization of aluminum tolerance mechanisms in sugarcane}

The aluminum related genes found in the literature were classified into nine groups, of which five groups contained genes with well defined biochemical functions associated with aluminum stress and two groups consisted of genes induced or repressed by aluminum but without further biological evidence for being related to aluminum tolerance mechanisms. Of the remaining two groups, one contained genes of unknown function while the other was made up of genes that exhibited no similarity with sugarcane genes.

In this paper, our discussion of the aluminum tolerance mechanisms that may be present in sugarcane is based on the aluminum-related genes found to be similar to sugarcane genes and on the functions of these genes.

\section{RESULTS}

Several sugarcane genes showed similarity to genes known to be related to aluminum tolerance mechanisms in other organisms, with all the genes presenting e-values below $10^{-5}$ being regarded as related to the genes described in the literature (Table I). The deduced sugarcane proteins were aligned with the ones described in the literature and the percentages of identity and similarity in these alignments were calculated. In some cases, a low percentage of similarity was found, probably indicating that the cap3 cluster consensi do not contain the full gene sequences or that the similarities were restricted to conserved domains.

The genes were classified based on their putative function in the different aluminum tolerance mechanisms (Table I). The first two groups comprise genes of known roles, related to external and internal aluminum tolerance mechanisms, respectively. Five groups include genes with known functions, whose roles in aluminum tolerance were not completely clear. The group of genes with unknown function includes all the remaining sugarcane genes that showed similarity with aluminum stress related genes. The last group comprises all genes that were reported as related to aluminum tolerance but that exhibited no similarity with sugarcane genes sampled in the SUCEST Project (e-value above $10^{-5}$ ). 


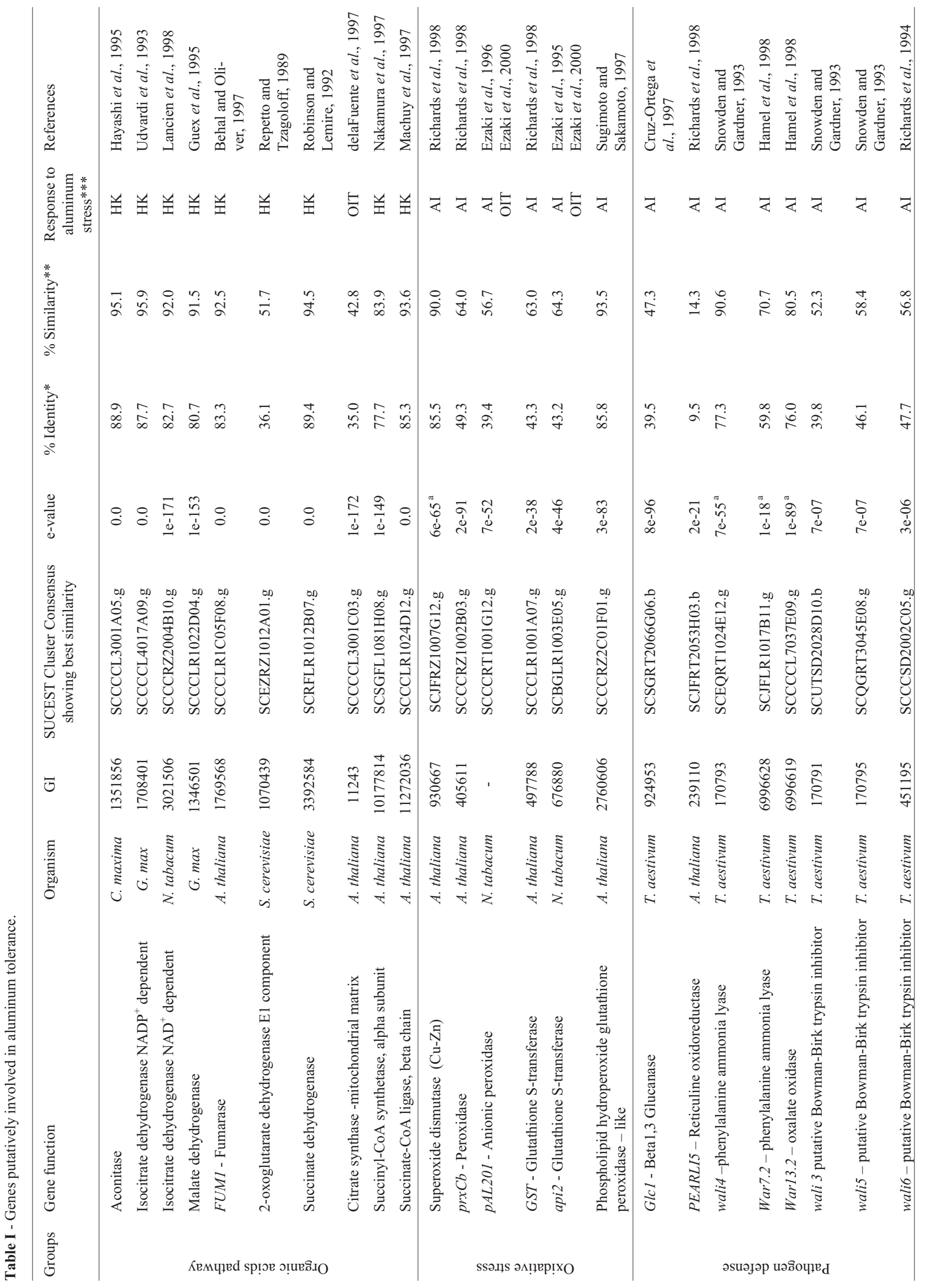




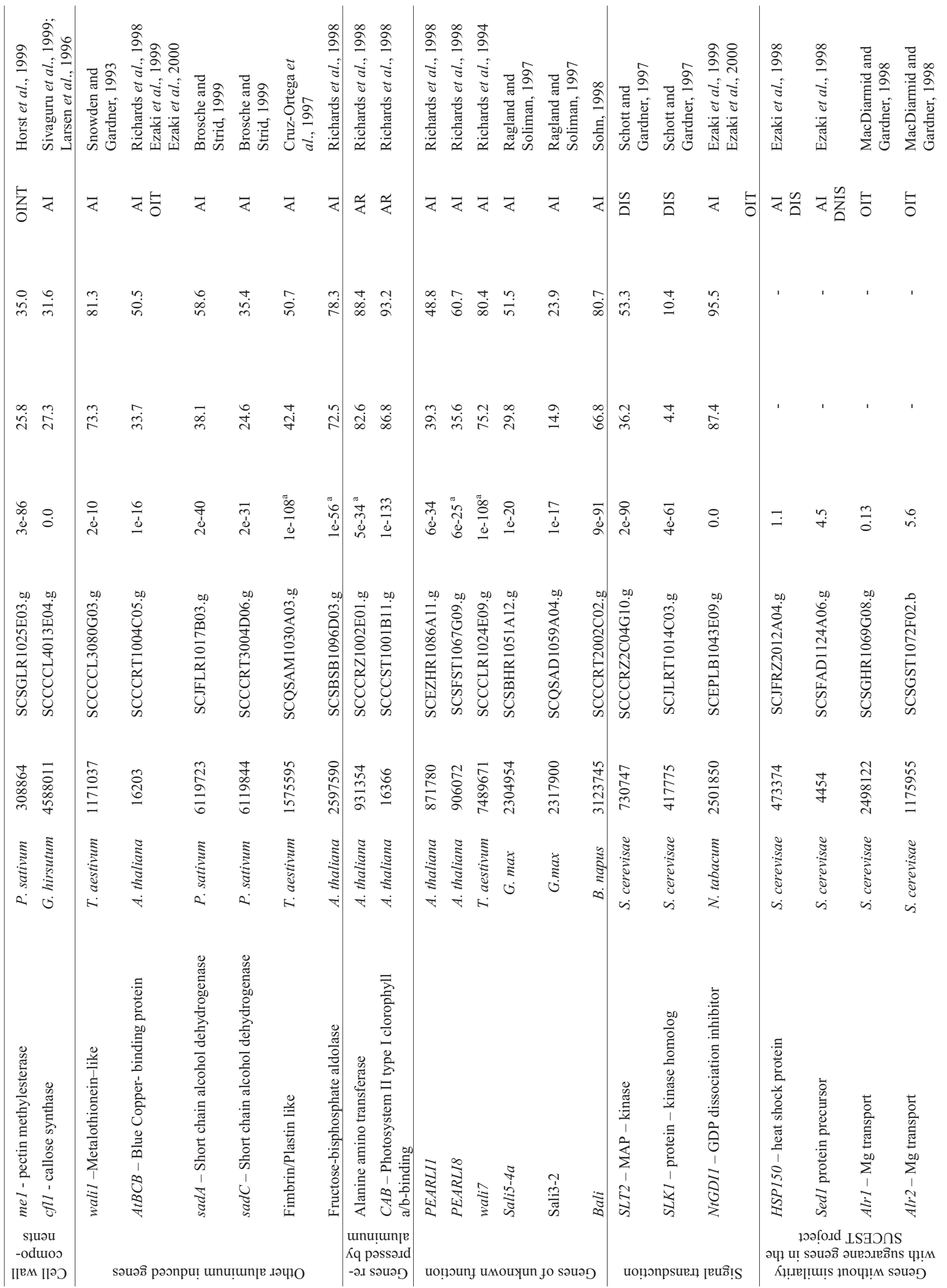



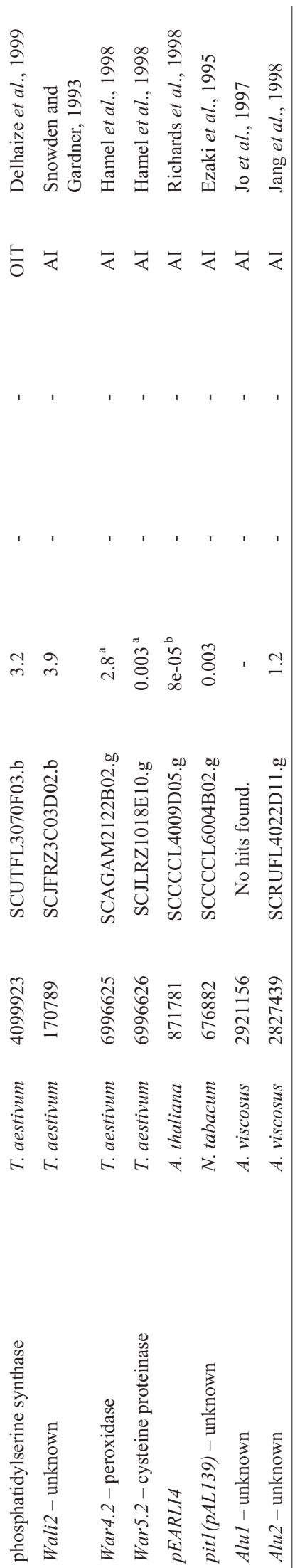

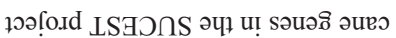

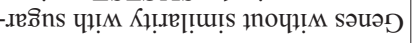

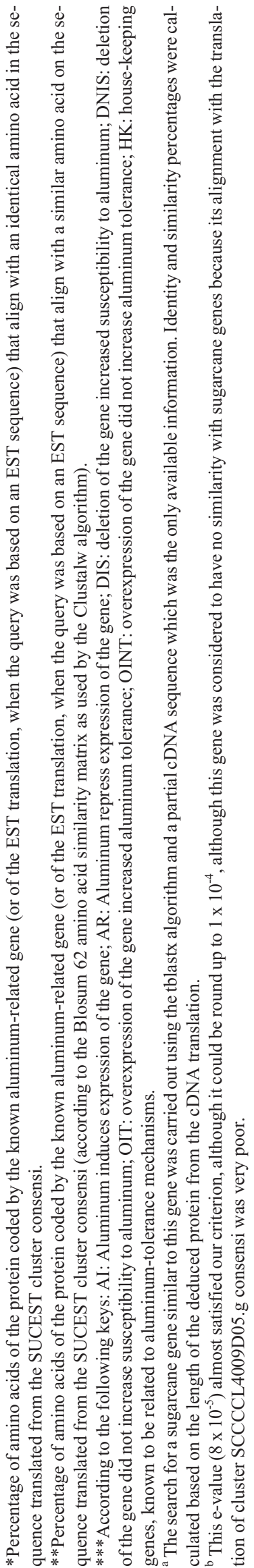

\section{DISCUSSION}

A high proportion of the genes involved in all sorts of aluminum tolerance mechanisms in other plants and microorganisms were identified in the SUCEST database, which could indicate that these mechanisms have been conserved among species, helping to explain how sugarcane overcomes aluminum toxicity.

There is strong evidence that secretion of organic acids from the roots is one of the mechanisms involved in aluminum tolerance in higher plants, but the process leading from the synthesis to the secretion of these organic acids are still unknown. For this reason, all key enzymes involved in this metabolic pathway were evaluated and found to be similar in sugarcane, as is to be expected due to their biochemical and physiological importance.

Organic acids are able to form strong complexes with aluminum which act in both major mechanisms of aluminum tolerance, either by chelating aluminum ions present in the apoplast and the rhizosphere (exclusion) or by the internal detoxification of this metal by reversing its toxic effects inside the cell (Ma, 2000). In tea plants (Camellia sinensis L.), aluminum is taken up and stored in the central vacuole as complexes with organic acids (Matsumoto et al., 1976). Internal detoxification of aluminum in the vacuoles of maize root apical cells has also been identified (Vazquez et al., 1999), while an aluminum tolerant variety of wheat was able to externally chelate this metal by the secretion of malic acid into the rhizosphere (Delhaize et al., 1993). External detoxification of aluminum by the secretion of organic acids such as citric, oxalic, succinic and/or malic acid from the root apex have also been reported for aluminum-tolerant cultivars of snapbean (Miyasaka et al., 1991), maize (Pellet et al., 1995) and Arabidopsis (Degenhardt et al., 1998), under aluminum stress. High aluminum tolerance in buckwheat has been associated with both internal (Ma et al., 1998) and external (Zheng et al., 1998) detoxification mechanisms due to oxalic acid, which forms a non-phytotoxic complex with aluminum and which is also secreted from the root tips. So, it can be seen that the kind of organic acids as well as the secretion pattern differ markedly between plant species (Ma, 2000). The most convincing evidence for the involvement of organic acid exudation in aluminum tolerance has been presented by Fuente et al. (1997) who produced transgenic tobacco and papaya over-expressing citrate synthase. The overproduction and exudation of citrate resulted in a significant increase in the aluminum tolerance of these transgenic plants. In rye citrate synthase activity has also been increased by exposure to aluminum (Li et al., 2000).

Another mechanism that may be involved in aluminum toxicity is oxidative stress activated by peroxidation of membrane lipids (Kochian, 1995). Richards et al (1998) reported that aluminum induced the expression of oxidative stress genes in Arabidopsis thaliana, thereby indicating that stress caused by this metal is closely related to oxida- 
tive stress. Among the oxidative stress genes induced by aluminum, sugarcane genes coding for superoxide dismutase, peroxidase, moderately anionic peroxidase, glutathione S-transferase and phospholipid hydroperoxide glutathione peroxidase-like protein were found. Superoxide dismutase is an enzyme that converts superoxide radicals to hydrogen peroxide and oxygen, thus playing a crucial role in antioxidant defense (Tsang et al., 1991; Van Camp et al., 1994). Peroxidase activities occur mostly at the cell wall, where these enzymes have been suggested to modulate cell wall rigidity and extensibility, thus reducing the rate of aluminum diffusion through the cell wall (Hamel et al., 1998). The moderately anionic peroxidases from tobacco are also highly induced in wounded stem tissue (Lagrimini and Rothstein, 1987). These enzymes have a moderate activity toward lignin precursors (Espelie et al., 1986) and are likely to be associated with the cell wall. Ezaki et al. (1996) speculated that the moderately anionic peroxidase has a function in healing cell membranes damaged by aluminum treatment. The glutathione S-transferase family of proteins catalyzes the conjugation of glutathione to a variety of electrophiles. Glutathione is one of the most important antioxidants and probably prevents the peroxidation of membrane lipids by aluminum ions (Ezaki et al., 1995). Sugimoto and Sakamoto (1997) suggested that phospholipid hydroperoxidase glutathione peroxidase-like protein catalyzes the reduction of the hydroperoxides of phospholipids in response to oxidative stress caused by diverse treatments, including exposure to aluminum. Glutathione reductases catalyzes the reduction of the oxidized form of glutathione (GSSG) to its reduced form (GSH) and has a central role in the cell response during stress, but there are no reports in the literature of the expression of genes coding for this enzyme in response to aluminum. However, we have found that aluminum induces higher levels of glutathione reductase activity in maize roots (Boscolo et al., unpublished results), indicating that the genes coding for this enzyme are also up-regulated by exposure to aluminum.

Genes related to pathogen response have also been reported to be induced by aluminum, and some were found to be similar to sugarcane genes. The expression of the $1,3-\beta$-glucanase gene is often associated with pathogen infection, particularly by fungi. Although its role in aluminum toxicity is unknown, Cruz-Ortega et al. (1997) suggested that this protein is synthesized as a protective response, because during aluminum stress roots are more susceptible to pathogen attack. This hypothesis is also a possible explanation for the induction by aluminum of other genes related to pathogen response. Reticuline oxireductase, also induced by aluminum, is involved in the formation of benzophenanthridine alkaloids in the response of plants to pathogenic attack (Richards et al., 1998). Phenylalanine ammonia-lyase (PAL) is a well-known defense protein that has been shown to accumulate in several different incompatible plant-pathogen combinations and in response to elicitors (Ebel and Cosio, 1994). This enzyme could play a beneficial role in detoxifying aluminum that has entered the symplasm, since PAL has been shown to catalyze the first step of multi-branched phenylpropanoid metabolism in higher plants (Hamel et al., 1998). Oxalate oxidase, an enzyme involved in the degradation of oxalate (accumulated in plant cells as the calcium salt), has been shown to accumulate during the fungal infection of barley (Zhang et al., 1995). Hamel et al. (1998) reported that PAL, cysteine proteinase, oxalate oxidase and a peroxidase were up-regulated in wheat in proportion to the level of aluminum, suggesting that these proteins may provide protection against ions of this metal by strengthening the cell wall of root cells. Another three genes induced by aluminum in wheat (wali3, wali5 and wali6) have also been found to be similar to some sugarcane genes. These wheat genes encode Bowman-Birk type trypsin inhibitors, an extensively studied family of protease inhibitors (Laskowsky and Kato, 1980), whose homologs in soybean have been shown to have antifungal activity (Chilosi et al., 2000) and have been suggested to be a defense against insect feeding (Belzunces et al., 1994).

In addition, genes coding for other proteins that participate in the dynamics of the cell wall may be associated with aluminum tolerance or susceptibility. Horst et al. (1999) showed that maize and potato mutants over-expressing pectinmethylesterase (PME) had a high negative charge on their pectin matrix and were more susceptible to aluminum stress. The degree of pectin methylation, mainly controlled by pectinmethylesterase, was quantitatively estimated and seemed to especially affect the negative charge density of the pectin matrix in certain defined root zones. However, it is not known how pectin content and the degree of methylation correlates with genotypical differences in aluminum tolerance, and the role of the pectin charge density of root apical cell wall in the tolerance of maize to aluminum needs to be clarified. Callose formation has been induced in the apical root cells of aluminum-sensitive maize cultivars (Sivaguru et al., 1999) and Arabidopsis mutants with increased sensitivity to aluminum (Larsen et al., 1996). A study using immuno-fluorescence and immuno-electron microscopic techniques combined with monoclonal antibodies against callose (Sivaguru et al., 2000) showed that aluminum-sensitive wheat root growth inhibition was closely associated with the blockage of plasmodesmata (cytoplasmic channels responsible for the intercellular movement of water, nutrients and for signaling) by callose deposition under aluminum stress, which could effectively block symplastic transport and communication in higher plants. One of the key enzymes acting in callose formation is callose synthase, which showed high similarity with genes in the SUCEST database.

Other stress related genes induced by aluminum were also found to have similarities with some sugarcane genes. 
Snowden and Gardner (1993) showed that a wheat gene coding for a metallothioneine-like protein (MLP) was identified as being up-regulated by aluminum and thought that it is highly unlikely that MLPs bind this metal, so it appears that aluminum must induce this gene by interfering with the plant's normal pathway for the uptake or homeostasis of other metal ions. A gene for blue copper binding $(B C B)$ protein, induced in wheat by aluminum (Richards et al., 1998), belongs to a family of genes that encode many membrane proteins with various suggested functions in plant metabolism, such as the regulation of the uptake of the ions of metals such as calcium, iron, manganese and zinc (Lin and $\mathrm{Wu}, 1994)$, redox reductions (VanGysel et al., 1993), and lignification of the cell wall (Drew and Gatehouse, 1994). The role of the $B C B$ gene in aluminum tolerance is not clear, but Ezaki et al. (1999) speculated that the BCB protein might restrict aluminum uptake across the plasma membrane by affecting the structural composition of the membrane.

Aluminum also induces the expression of genes that are not directly related to the stress response or other known defense mechanisms. We found sugarcane genes which are similar to two pea genes ( $s a d A$ and $s a d C$ genes) that are up-regulated by aluminum and which encode short-chain alcohol dehydrogenases (ADHs). Several genes with high similarity to the sad genes are considered to encode proteins involved in steroid metabolism, so it is possible that SAD proteins are involved in the metabolism of phytosteroids (Brosche and Strid, 1999). However, short-chain ADHs are also reported to be involved in oxidation of the hydroxyl groups of diverse substrates such as sugar, acetoacetyl-CoA, mammalian prostaglandins and diols, in addition to steroids (Persson et al., 1991). All these compounds, as well as other unidentified hydroxyl-containing chemical species, are possible substrates for SAD proteins. A gene encoding a fimbrin-like cytoskeletal protein, induced in pea by aluminum (Cruz-Ortega et al., 1997), also showed similarity with sugarcane genes. Fimbrins are a highly conserved family of actin filament bundling proteins, which are probably utilized by plants to maintain the integrity and functional array of actin filaments in the cell cytoskeleton. Cruz-Ortega et al. (1997) suggested that the increased tension of the cytoskeletal actin associated with aluminum toxicity may involve extensive cross-linking of actin filaments by fimbrins, leading to up-regulation of fimbrin gene expression to replenish cellular fimbrin pools. Another gene, induced by aluminum in Arabidopsis thaliana and similar to a sugarcane gene, encodes a fructose-bisphosphate aldolase (Richards et al., 1998). This protein is involved in both glycolysis and gluconeogenesis in plastids, and catalyzes the formation of fructose-bisphosphate and sedoheptulose-bisphosphate in photosynthesizing chloroplasts (Razdan et al., 1992), although its role in aluminum tolerance is not clear.
Two genes have been reported as being down-regulated by aluminum in Arabidopsis thaliana (Richards et al., 1998), both of which show similarity with sugarcane genes. One of these genes belongs to the chlorophyll $\mathrm{a} / \mathrm{b}$-binding $(C A B)$ gene family, which is a distinct class of structurally and evolutionary related pigment-binding proteins found in chloroplast thylakoid membranes (McGrath et al., 1992). The other gene shows similarity with alanine aminotransferase, a pyridoxal phosphate-dependent enzyme that operates in a wide range of metabolic pathways, catalyzing the reversible transfer of an amino group from alanine to 2-oxoglutarate to form pyruvate and glutamate (Son and Sugiyama, 1992). It has been suggested by Richards et al. (1998) that the shutdown of these transcripts might reflect the response of a central metabolic pathway to aluminum stress.

As to be expected, the complex regulation of gene expression and of several metabolic pathways in response to aluminum toxicity also involves genes responsible for signal transduction. Several sugarcane genes were found to be similar to signal transduction genes from other organisms, these genes being a mitogen-activated protein kinase (MAP-kinase, SLT2 gene), a protein kinase homolog (SLK1 gene) and a GDP dissociation inhibitor (NtGDI1 gene). The MAP-kinase functions in a signal transduction cascade downstream of protein kinase C (PKC), and has a known role in regulating the cell cycle under stress conditions (Costigan and Snyder, 1994). SLK1 belongs to the same pathway of SLT2 MAP kinase (SLT2 pathway) and encodes the corresponding MAP kinase-kinase. Schott and Gardner (1997) have shown that yeasts with a mutant SLT2 pathway are aluminum sensitive, these authors suggesting that this results in failure of the cells properly to cease division in the presence of toxic levels of aluminum. The expression of NtGDII in response to aluminum toxicity seems to cause an increased afflux of aluminum (Ezaki et al., 1999). GDI proteins regulate vesicular traffic at many stages of the exocytic and endocytic transport pathways in various organisms (Matsui et al., 1990). Ezaki et al. (1999) has suggested that the NtGDI1 protein increases aluminum release from yeast cells by stimulating the vesicle transport system.

Sugarcane genes similar to several genes with unknown function, but reported as being regulated by aluminum stress, were also found (Table I). The lack of information on the function of these genes shows how far we are from a complete knowledge of the mechanisms involved in aluminum tolerance in plants. At the end of Table I we have listed all the genes reported to be involved in aluminum-tolerance in other species but which did not show similarity with sugarcane genes. These results suggest that the mechanisms of aluminum tolerance in which these genes are involved may be species-specific, or display high genetic divergence among organisms. It is also possible that some genes may be expressed only under aluminum 
stress and since the SUCEST database contains data from plants which were not treated with aluminum specific induced genes may not have been sampled.

The results presented in this paper show that sugarcane has genes similar to most of the genes related to aluminum stress in other species, suggesting that sugarcane may activate a wide array of defenses against aluminum toxicity. However, further experiments are needed to determine the role of these genes in aluminum tolerance in sugarcane and our group is using DNA macroarrays containing the genes we have cataloged (in this and other research projects) to identify changes in sugarcane gene expression in response to aluminum stress. The high level of gene order and conservation of function among related grasses (Guimarães et al., 1997; Ming et al., 1998) suggest that the genetic resources used by sugarcane can be applied to other species thus increasing the usefulness of the SUCEST project.

\section{RESUMO}

Alumínio (Al) é um dos principais fatores que afetam o desenvolvimento de plantas em solos ácidos, reduzindo substancialmente a produtividade agrícola. Na América do Sul, cerca de $66 \%$ da superfície do solo apresenta acidez, onde a alta saturação de alumínio é uma das maiores limitações à prática agrícola. Apesar do crescente número de estudos, uma compreensão completa das bases bioquímicas e moleculares da tolerância ao alumínio em plantas está longe de ser alcançada. No caso da cana-de-açúcar, não há nada publicado sobre a regulação gênica induzida durante $o$ stress por alumínio. O objetivo deste trabalho foi identificar genes de cana-de-açúcar relacionados com as várias vias metabólicas reconhecidamente envolvidas na resposta à toxidez do alumínio em outras espécies de plantas e leveduras. Para a maioria dos genes relacionados com alumínio em outras espécies foram identificados similares em cana-de-açúcar, tais como aqueles que codificam enzimas que combatem o stress oxidativo ou a infestação por patógenos, proteínas responsáveis pela exudação de ácidos orgânicos e pela transdução de sinais. O papel desses genes na tolerância ao alumínio é revisado. Devido ao alto grau de conservação do genoma entre espécies próximas de gramíneas como milho, cevada, sorgo e cana-de-açúcar, esses genes serão uma ferramenta valiosa para a melhor compreensão e manipulação da tolerância ao alumínio nestas espécies.

\section{ACKNOWLEDGMENTS}

We thank Michel G. A. Vincentz, Felipe R. da Silva and Renato V. dos Santos for helpful discussions. This work was supported by a grant from FAPESP (00/07433-0) to MM. RDD and JMF were recipients of fellowships from FAPESP. FENC was supported by a CAPES fellowship.

\section{REFERENCES}

Azeredo, D.F. (1982). Alumínio no crescimento e na concentração de nutrientes em diferentes cultivares de cana-de-açúcar (Saccharum spp). Piracicaba, Escola Superior de Agricultura "Luiz de Queiroz" - USP,1982 55p Tese (Mestrado).

Baligar, V.C. and Ahlrichs, J.L. (1998). Nature and Distribution of Acid Soils in the World. In: Proceedings of a Workshop to Develop a Strategy for Collaborative Research and Dissemination of Technology in Sustainable Crop Production in Acid Savannas and other Problem Soils of the World. (Schaffert, R.E., ed.), Purdue University, West Lafayette, IN pp: $1-11$.

Behal, R.H. and Oliver, D.J. (1997). Biochemical and molecular characterization of fumarase from plants: Purification and characterization of the enzyme - Cloning, sequencing, and expression of the gene. Arch. Biochem. Biophys. 348: 65-74.

Belzunces, L.P., Lenfant, C., Dipasquale, S. and Colin, M.E. (1994). In-vivo and in-vitro effects of wheat-germ-agglutinin and Bowman-Birk soybean trypsin-inhibitor, 2 potential transgene products, on midgut esterase and protease activities from Apis mellifera. Comp. Biochem. Physiol. B-Biochem. Mol. Biol. 109: 63-69.

Brosche, M. and Strid, A. (1999). Cloning, expression, and molecular characterization of a small pea gene family regulated by low levels of ultraviolet $B$ radiation and other stresses. Plant Physiol. 121: 479-487.

Chilosi, G., Caruso, C., Caporale, C., Leonardi, L., Bertini, L., Buzi, A., Nobile, M., Magro, P. and Buonocore, V. (2000). Antifungal activity of a Bowman-Birk-type trypsin inhibitor from wheat kernel. J. Phytopathol. 148: 477-481.

Costigan, C. and Snyder, M. (1994). SLK1, a yeast homolog of MAP kinase activators, has a Ras/Camp independent role in nutrient sensing. Mol. Gen. Genet. 243: 286-296.

Cruz-Ortega, R., Cushman, J.C. and Ownby, J.D. (1997). cDNA clones encoding 1,3-beta-glucanase and a fimbrin-like cytoskeletal protein are induced by $\mathrm{Al}$ toxicity in wheat roots. Plant Physiol. 114: 1453-1460.

Degenhardt, J., Larsen, P.B., Howell, S.H. and Kochian, L.V. (1998). Aluminum resistance in the Arabidopsis mutant alr-104 is caused by an aluminum-induced increase in rhizosphere pH. Plant Physiol. 117: 19-27.

Dela Fuente, J.M., Ramirez Rodriguez, V., Cabrera Ponce, J.L. and Herrera Estrella, L. (1997). Aluminum tolerance in transgenic plants by alteration of citrate synthesis. Science 276: $1566-1568$.

Delhaize, E., Hebb, D.M., Richards, K.D., Lin, J.M., Ryan, P.R. and Gardner, R.C. (1999). Cloning and expression of a wheat (Triticum aestivum L.) phosphatidylserine synthase cDNA - Overexpression in plants alters the composition of phospholipids. J. Biol. Chem. 274: 7082-7088.

Delhaize, E. and Ryan, P.R. (1995). Aluminum toxicity and tolerance in plants. Plant Physiol. 107: 315-321.

Delhaize, E., Ryan, P.R. and Randall, P.J. (1993). Aluminum tolerance in wheat (Triticum aestivum L) Aluminum-stimulated excretion of malic-acid from root apices. Plant Physiol. 103: 695-702.

Drew, J.E. and Gatehouse, J.A. (1994). Isolation and characterization of a pea pod cDNA encoding a putative blue copper protein correlated with lignin deposition. J. Exp. Bot. 45: 1873-1884. 
Ebel, J. and Cosio, E.G. (1994). Elicitors of plant defense responses. Int. Rev. Cytol. 148: 1-36.

Espelie, K.E., Franceschi, V.R. and Kolattukudy, P.E. (1986). Immunocytochemical localization and time course of appearance of an anionic peroxidase associated with suberization in wound-healing potato-tuber tissue. Plant Physiol. 81: 487-492.

Ezaki, B., Gardner, R.C., Ezaki, Y., Kondo, H. and Matsumoto, H. (1998). Protective roles of two aluminum (Al)-induced genes, HSP150 and SED1 of Saccharomyces cerevisiae, in $\mathrm{Al}$ and oxidative stresses. FEMS Microbiol. Lett. 159: 99-105.

Ezaki, B., Gardner, R.C., Ezaki, Y. and Matsumoto, H. (2000). Expression of aluminum-induced genes in transgenic Arabidopsis plants can ameliorate aluminum stress and/or oxidative stress. Plant Physiol. 122: 657-665.

Ezaki, B., Sivaguru, M., Ezaki, Y., Matsumoto, H. and Gardner, R.C. (1999). Acquisition of aluminum tolerance in Saccharomyces cerevisiae by expression of the $B C B$ or NtGDI1 gene derived from plants. FEMS Microbiol. Lett. 171: 81-87.

Ezaki, B., Tsugita, S. and Matsumoto, H. (1996). Expression of a moderately anionic peroxidase is induced by aluminum treatment in tobacco cells: Possible involvement of peroxidase isozymes in aluminum ion stress. Physiol. Plant. 96: 21-28.

Ezaki, B., Yamamoto, Y. and Matsumoto, H. (1995). Cloning and sequencing of the cDNAs induced by aluminum treatment and Pi-starvation in cultured tobacco cells. Physiol. Plant. 93: 11-18.

Gorlach, J., Volrath, S., Knauf Beiter, G., Hengy, G., Beckhove, U., Kogel, K.H., Oostendorp, M., Staub, T., Ward, E., Kessmann, H. and Ryals, J. (1996). Benzothiadiazole, a novel class of inducers of systemic acquired resistance, activates gene expression and disease resistance in wheat. Plant Cell 8: 629-643.

Guex, N., Henry, H., Flach, J., Richter, H. and Widmer, F. (1995). Glyoxysomal malate-dehydrogenase and malate synthase from soybean cotyledons (Glycine $\max \mathrm{L}$ ) - enzyme association, antibody production and cDNA cloning. Planta 197: 369-375.

Guimarães, C.T., Sills, G.R. and Sobral, B.W.S. (1997). Comparative mapping of Andropogoneae: Saccharum L. (sugarcane) and its relation to sorghum and maize. Proc. Natl. Acad. Sci. USA 94: 14261-14266.

Gysel, A., Montagu, M. and Inze, D. (1993). A negatively light-regulated gene from Arabidopsis thaliana encodes a protein showing high similarity to blue copper-binding proteins. Gene 136: 79-85.

Hamel, F., Breton, C. and Houde, M. (1998). Isolation and characterization of wheat aluminum-regulated genes: possible involvement of aluminum as a pathogenesis response elicitor. Planta 205: 531-538.

Haranishimura, I., Takeuchi, Y. and Nishimura, M. (1993). Molecular characterization of a vacuolar processing enzyme related to a putative cysteine proteinase of Schistosoma mansoni. Plant Cell 5: 1651-1659.

Hayashi, M., Debellis, L., Alpi, A. and Nishimura, M. (1995). Cytosolic aconitase participates in the glyoxylate cycle in etiolated pumpkin cotyledons. Plant Cell Physiol. 36: 669-680.
Horst, W.J., Schmohl, N., Kollmeier, M., Baluska, F. and Sivaguru, M. (1999). Does aluminium affect root growth of maize through interaction with the cell wall - plasma membrane - cytoskeleton continuum? Plant Soil 215: 163-174.

Jang, Y.S., Kim, K.Y., Park, J.I., Jo, J.K. and Chung, W.I. (1998). Direct Submission. Biological Sciences, Korea Advanced Institute of Science and Technology, 373-1 Kusong-dong, Yusong-gu, Taejon 305-701, Korea.

Jo, J., Jang, Y.S., Kim, K.Y., Kim, M.H., Kim, I.J. and Chung, W.I. (1997). Isolation of $A L U 1-P$ gene encoding a protein with aluminum tolerance activity from Arthrobacter viscosus. Biochem. Biophys. Res. Commun. 239: 835-839.

Kinraide, T.B. and Parker, D.R. (1989). Assessing the phytotoxicity of mononuclear hydroxy-aluminum. Plant Cell Environ. 12: 479-487.

Kochian, L.V. (1995). Cellular mechanisms of aluminum toxicity and resistance in plants. Ann Rev Plant Physiol. Plant Mol Biol 46: 237-260.

Lagrimini, L.M. and Rothstein, S. (1987). Tissue-specificity of tobacco peroxidase isozymes and their induction by wounding and tobacco mosaic-virus infection. Plant Physiol. 84: 438-442.

Lancien, M., Gadal, P. and Hodges, M. (1998). Molecular characterization of higher plant NAD-dependent isocitrate dehydrogenase: evidence for a heteromeric structure by the complementation of yeast mutants. Plant J. 16: 325-333.

Landell, M.G.A. (1989). Comportamento da cana-de-açúcar (Saccharum spp) frente a niveis de alúmínio, em solução nutritiva. FCAV/UNESP, $117 \mathrm{p}$ Tese (Doutoramento).

Larsen, P.B., Tai, C.Y., Kochian, L.V. and Howell, S.H. (1996). Arabidopsis mutants with increased sensitivity to aluminum. Plant Physiol. 110: 743-751.

Laskowsky, M. and Kato, I. (1980). Protein inhibitors of proteinases. Ann. Rev. Biochem. 49: 593-626.

Li, X.F., Ma, J.F. and Matsumoto, H. (2000). Pattern of aluminum-induced secretion of organic acids differs between rye and wheat. Plant Physiol. 123: 1537-1543.

Lin, S.L. and Wu, L. (1994). Effects of copper concentration on mineral nutrient-uptake and copper accumulation in protein of copper-tolerant and copper-nontolerant Lotus purshianus L. Ecotoxicol. Environ. Saf. 29: 214-228.

Ma, J.F. (2000). Role of organic acids in detoxification of aluminum in higher plants. Plant Cell Physiol. 41: 383-390.

Ma, J.F., Hiradate, S. and Matsumoto, H. (1998). High aluminum resistance in buckwheat - II. Oxalic acid detoxifies aluminum internally. Plant Physiol. 117: 753-759.

MacDiarmid, C.W. and Gardner, R.C. (1998). Overexpression of the Saccharomyces cerevisiae magnesium transport system confers resistance to aluminum ion. J. Biol. Chem. 273: 1727-1732.

Matsui, Y., Kikuchi, A., Araki, S., Hata, Y., Kondo, J., Teranishi, Y. and Takai, Y. (1990). Molecular cloning and characterization of a novel type of regulatory protein (GDI) for SMG P25A, a RAS P21-like GTP-binding protein. Mol. Cell. Biol. 10: 4116-4122.

Machuy, N., Klein, M. and Mueller-Roeber, B. (1997). Direct Submission. Submitted (AUG-1997) to the EMBL Data Library.

Matsumoto, H., Hirasawa, E., Morimura, S. and Takahashi, E. (1976). Localization of aluminum in tea leaves. Plant Cell Physiol. 17: 627-631. 
McGrath, J.M., Terzaghi, W.B., Sridhar, P., Cashmore, A.R. and Pichersky, E. (1992). Sequence of the 4th and 5th photosystem-ii type-i chlorophyll a/b-binding protein genes of Arabidopsis thaliana and evidence for the presence of a full complement of the extended $C A B$ gene family. Plant Mol. Biol. 19: 725-733.

Ming, R., Liu, S.C., Lin, Y.R., da Silva, J., Wilson, W., Braga, D., van Deynze, A., Wenslaff, T.F., Wu, K.K., Moore, P.H., Burnquist, W., Sorrells, M.E., Irvine, J.E. and Paterson, A.H. (1998). Detailed alignment of Saccharum and Sorghum chromosomes: Comparative organization of closely related diploid and polyploid genomes. Genetics 150: 1663-1682.

Miyasaka, S.C., Buta, J.G., Howell, R.K. and Foy, C.D. (1991). Mechanism of aluminum tolerance in snapbeans - root exudation of citric-acid. Plant Physiol. 96: 737-743.

Nakamura, Y., Sato, S., Kaneko, T., Kotani, H., Asamizu, E., Miyajima, N. and Tabata, S. (1997). Structural analysis of Arabidopsis thaliana chromosome 5. III. Sequence features of the regions of 1,191,918 bp covered by seventeen physically assigned P1 clones. DNA Res. 4: 401-414.

Pellet, D.M., Grunes, D.L. and Kochian, L.V. (1995). Organic-acid exudation as an aluminum-tolerance mechanism in maize (Zea mays L). Planta 196: 788-795.

Persson, B., Krook, M. and Jornvall, H. (1991). Characteristics of short-chain alcohol dehydrogenases and related enzymes. Eur. J. Biochem 200: 537-543.

Ragland, M. and Soliman, K.M. (1997). Sali5-4a and Sali3-2. Two genes induced by aluminum in soybean roots. Plant Physiol. 114: 395.

Razdan, K., Heinrikson, R.L., Zurcherneely, H., Morris, P.W. and Anderson, L.E. (1992). Chloroplast and cytoplasmic enzymes - isolation and sequencing of cDNAs coding for 2 distinct pea chloroplast aldolases. Arch. Biochem. Biophys. 298: 192-197.

Repetto, B. and Tzagoloff, A. (1989). Structure and regulation of $K G D 1$, the structural gene for yeast alpha-ketoglutarate dehydrogenase. Mol. Cell Biol. 9: 2695-2705.

Richards, K.D., Schott, E.J., Sharma, Y.K., Davis, K.R. and Gardner, R.C. (1998). Aluminum induces oxidative stress genes in Arabidopsis thaliana. Plant Physiol. 116: 409-418.

Richards, K.D., Snowden, K.C. and Gardner, R.C. (1994). Wali6 and wali7 - genes induced by aluminum in wheat (Triticum aestivum L) roots. Plant Physiol. 105: 1455-1456.

Robinson, K.M. and Lemire, B.D. (1992). Isolation and nucleotide-sequence of the Saccharomyces cerevisiae gene for the succinate-dehydrogenase flavoprotein subunit. J. Biol. Chem. 267: 10101-10107.

Schott, E.J. and Gardner, R.C. (1997). Aluminum-sensitive mutants of Saccharomyces cerevisiae. Mol. Gen. Genet. 254: 63-72.

Sivaguru, M., Baluska, F., Volkmann, D., Felle, H.H. and Horst, W.J. (1999). Impacts of aluminum on the cytoskel- eton of the maize root apex. Short-term effects on the distal part of the transition zone. Plant Physiol. 119: 1073-1082.

Sivaguru, M., Fujiwara, T., Samaj, J., Baluska, F., Yang, Z.M., Osawa, H., Maeda, T., Mori, T., Volkmann, D. and Matsumoto, H. (2000). Aluminum-induced 1-3-beta-D-glucan inhibits cell-to-cell trafficking of molecules through plasmodesmata. A new mechanism of aluminum toxicity in plants. Plant Physiol. 124: 991-1005.

Snowden, K.C. and Gardner, R.C. (1993). Five genes induced by aluminum in wheat (Triticum aestivum L) roots. Plant Physiol. 103: 855-861.

Sohn, U. (1998). Direct Submission. Uik Sohn, Kyungpook National University, Department of Genetic Engineering; 1370 Sankyuk-Dong, Puk-Ku, Taegu 702-701, Korea.

Son, D.Y. and Sugiyama, T. (1992). Molecular-cloning of an alanine aminotransferase from NAD-malic enzyme type-c4 plant Panicum miliaceum. Plant Mol. Biol. 20: 705-713.

Sugimoto, M. and Sakamoto, W. (1997). Putative phospholipid hydroperoxide glutathione peroxidase gene from Arabidopsis thaliana induced by oxidative stress. Genes Genet. Syst. 72: 311-316.

Taylor, G.J. (1991). Overcoming barriers to understand cellular basis of aluminum resistance. Plant Soil 171: 89-103.

Thompson, J.D., Higgins, D.G. and Gibson, T.J. (1994). Clustal-W - Improving the sensitivity of progressive multiple sequence alignment through sequence weighting, position-specific gap penalties and weight matrix choice. $\mathrm{Nucl}$. Acid. Res. 22: 4673-4680.

Tsang, E.W.T., Bowler, C., Hérouat, D., Van Camp, W., Villarroel, R., Genetello, C., Van Montagu, M. and Inzé, D. (1991). Differential regulation of superoxide dismutase in plants exposed to environmental stress. Plant Cell 3: 783-792.

Udvardi, M.K., McDermott, T.R. and Kahn, M.L. (1993). Isolation and characterization of a cDNA encoding NADP+ -specific isocitrate dehydrogenase from soybean (Glycine max). Plant Mol. Biol. 21: 739-752.

Van Camp, W., Willekens, H., Bowler, C., Van Montagu, M., Inzé, D., Reupold-Popp, P., Sandermann, H. Jr. and Langebartels, C. (1994). Elevated levels of superoxide dismutase protect transgenic plants against ozone damage. Biotechnology 12: 165-168.

Vazquez, M.D., Poschenrieder, C., Corrales, I. and Barcelo, J. (1999). Change in apoplastic aluminum during the initial growth response to aluminum by roots of a tolerant maize variety. Plant Physiol. 119: 435-444.

Zhang, Z.G., Collinge, D.B. and Thordalchristensen, H. (1995). Germin-like oxalate oxidase, a $\mathrm{H}_{2} \mathrm{O}_{2}$-producing enzyme, accumulates in barley attacked by the powdery mildew fungus. Plant J. 8: 139-145.

Zheng, S.J., Ma, J.F. and Matsumoto, H. (1998). High aluminum resistance in buckwheat - I. Al-induced specific secretion of oxalic acid from root tips. Plant Physiol. 117: 745-751. 